\title{
TERIPARATIDE INFUSION FOR POST-THYROIDECTOMY HYPOCALCAEMIA: A CASE REPORT
}

\author{
Hamdan MK, Bashir J, Khan I, Aldridge A, Okosieme OE, Agarwal N \\ Diabetes \& Endocrinology Centre \\ Prince Charles Hospital
}

\section{INTRODUCTION}

We present a case of 68 year old female who developed symptomatic hypocalcaemia post-thyroidectomy, which she had for multinodular goitre. Previously she had ileostomy for severe faecal incontinence. Other medical problems include active colitis of indeterminate histology, duodenal ulcer and diverticular disease.

Despite treatment with suprapharmacological doses of oral calcium supplements, she remained severely hypocalcaemic, and often presented to hospital with tetany.

Transient hypocalcaemia is common following thyroidectomy. However severe refractory hypocalcaemia is rare. We present this case which was challenging to manage with conventional therapies. She successfully responded to a continuous infusion of teriparatide.

Table 1 shows comparison of levels pre- and post-operatively. Other causes of hypocalcaemia were excluded and concomitant Vitamin D deficiency was treated.

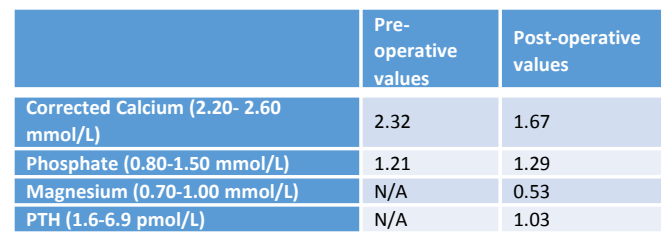

Table 1

STEPWISE MANAGEMENT FOR HYPOCALCAEMIA AND HYPOMAGNESAEMIA IN OUT PATIENT AND RESPONSE

\begin{tabular}{|c|l|l|l|l|}
\hline $\begin{array}{l}\text { Step } \\
\text { Number }\end{array}$ & Timeline & $\begin{array}{l}\text { PTH } \\
\text { (pmol/L) }\end{array}$ & $\begin{array}{l}\text { Corrected } \\
\text { Calcium } \\
\text { (mmol/L) }\end{array}$ & Ongoing Treatment \\
\hline 1 & $\begin{array}{l}\text { Mar } \\
2012\end{array}$ & 1.03 & 2.24 & $\begin{array}{l}\text { Alpha calcidol 0.25 mcg BD + } \\
\text { Calcichew D3 (6 tabs/day) }\end{array}$ \\
\hline 2 & Jul 2012 & 2.39 & 1.90 & $\begin{array}{l}\text { Calcitriol 2.25 mcg BD + } \\
\text { Sandocal 1g (1 tab QDS)+ } \\
\text { Weekly intravenous calcium \& } \\
\text { magnesium infusion }\end{array}$ \\
\hline 3 & $\begin{array}{l}\text { Aug } \\
2012\end{array}$ & 1.78 & 2.04 & $\begin{array}{l}\text { Calcitriol 2.25 mcg BD + } \\
\text { Sandocal 1g (1 tab QDS) + } \\
\text { Teriparatide 20 mcg SC } \\
\text { injections BD ) + } \\
\text { Weekly intravenous calcium \& } \\
\text { magnesium infusion }\end{array}$ \\
\hline 4 & Jan 2013 & 1.94 & 1.64 & $\begin{array}{l}\text { Calcitriol 2.25 mcg BD + } \\
\text { Sandocal 1g (1 tab QDS) + } \\
\text { Teriparatide 40mcg BD SC } \\
\text { injections ) + } \\
\text { Weekly intravenous calcium \& } \\
\text { magnesium infusion }\end{array}$ \\
\hline 5 & $\begin{array}{l}\text { Jun } \\
\text { 2013 }\end{array}$ & 1.70 & 1.89 & $\begin{array}{l}\text { Teriparatide infusion 40 mcg/ } \\
\text { 24 hours only }\end{array}$ \\
\hline 6 & Jan 2014 & 1.30 & 2.32 & $\begin{array}{l}\text { Teriparatide infusion 60 mcg / } \\
\text { 24 hours only }\end{array}$ \\
\hline
\end{tabular}

$\mathrm{mmol} / \mathrm{L}$

\section{Variations in Calcium / Phosphate/ Magnesium levels in}

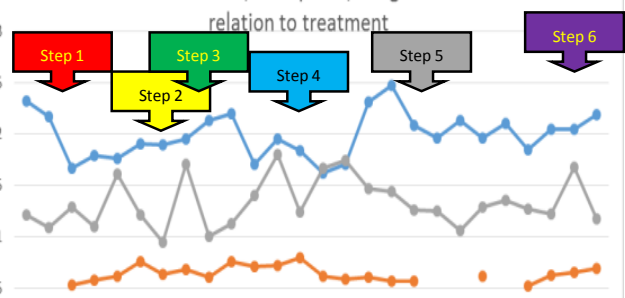

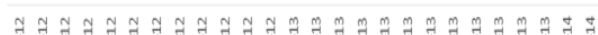

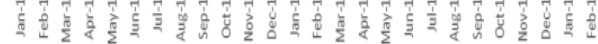

$\rightarrow$ Calcium $\rightarrow$ Magnesium $\rightarrow$-Phosphate

Graph showing serum calcium, magnesium and phosphate levels in response to different treatments. Treatment details are numbered and colour-coded

\section{DISCUSSION}

We faced few challenges in managing this patient with refractory hypocalcaemia post-thyroidectomy. She had multiple hospital admissions with symptomatic hypocalcaemia requiring intravenous replacement. To-date she had 10 admissions, often followed by prolonged hospital stay. In addition, she also required regular attendances to the Medical Day Unit for blood monitoring as well as intravenous treatment for less severe presentations.

As part of the intended long term therapy, she was initially commenced on oral calcium, magnesium and vitamin D tablets. However despite increasing the doses, the serum levels remained low.

We observed 3 limitations with oral therapies:

- Intolerance to calcium and magnesium salts, which were associated with worsening of gastrointestinal symptoms (nausea and high stoma output)

- Intermittent flare-up of colitis, which coincided with hypocalcaemia

- Failure to obtain optimal levels of calcium and magnesium despite suprapharmacological doses

Following literature reviews on Teriparatide treatment for hypocalcaemia $(1,2)$, we introduced subcutaneous Teriparatide injections in addition to the oral therapies. The initial dose was $20 \mathrm{mcg}$ BD, which was later increased to $40 \mathrm{mcg}$ BD. However despite this, serum calcium level remained suboptimal requiring multiple admissions for intravenous replacement. We suspected this could be due an underlying physiological mechanism as explained by J.Satterwhite et al (3). From their observation, Teriparatide injections transiently increased serum calcium levels but these returned to pre-dose levels 16 hours after each dose. Persistent hypercalcemia was not observed. Following once-daily subcutaneous administration, Teriparatide produces a modest but transient increase in serum calcium, consistent with the known effects of endogenous PTH on mineral metabolism.

In view of failure of treatment, we switched the Teriparatide injections to subcutaneous continuous infusion at a dose of 40 mcg over 24 hours. It was later increased to $60 \mathrm{mcg}$ over 24 hours and therapeutic sustained calcium levels were achieved. This led to significant reduction in the number of her hospital admissions.

TERIPARATIDE: MODE OF ACTION

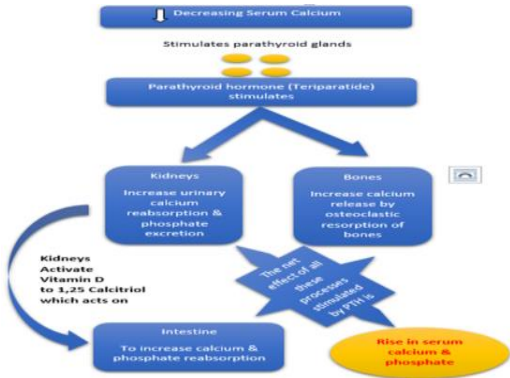

CONCLUSION

Continuous subcutaneous infusion of Teriparatide has been shown to be safe and effective in the management of this patient who has refractory hypocalcaemia post-thyroidectomy. We will continue to observe its effectiveness, development of side effects as well as resistance.

SYRINGE DRIVER DEVICE USED FOR DELIVERY OF TERIPARATIDE INFUSION
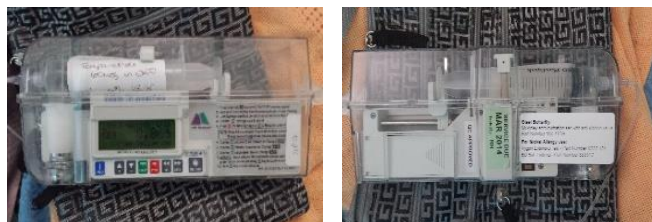

Puig-Domingo $M$, Diaz-Soto $G$ et al. Successful treatment of vitamin D unresponsive hypoparathyroidism with multiple subcutaneous infusion of teriparatide. Eur J Endocrinol. 2008 Nov, 159(5):653-7 Diaz-Soto G, Mora-Porta M et al. Efficacy and safety of long term treatment of unresponsive
hypoparathyroidism using multiple subcutaneous infusion of teriparatide. Horm Metab Res. 2012 Sep; $44(9): 708-10$ Satterwhite J, Heathman M, Miller PD, Marin F, Glass EV, Dobnig H. Pharmacokinetics of teriparatide (rhPTH[1-34]) and calcium $\mathrm{M}$. Int 2010 Dec: $87(6) \cdot 485-92$ 